\title{
ONLINE LEARNING AT UNIVERSITIES: POLISH-UKRAINIAN EXPERIENCE
}

\author{
Wladyslaw Wornalkiewicz \\ The Academy of Management and Administration in Opole \\ Niedziałkowskiego Str. 18, Opole, 45085, Poland \\ Wladyslaw.wornalkiewicz@wszia.opole.com \\ Olena Taranukha \\ National Transport University \\ Mykhaila Omelianovycha-Pavlenka Str. 1, Kyiv, 01010, Ukraine \\ e.taranukha@ukr.net, orcid.org/0000-0001-6787-0877 \\ Olena Fonariuk \\ Zhytomyr Ivan Franko State University \\ Velyka Berdychivska Str. 40, Zhytomyr, 10002, Ukraine \\ f-ev@i.ua, orcid.org/0000-0001-7879-5884
}

\begin{abstract}
The article presents a study of the organization of cooperation between a teacher and students in online learning. This applies to online classes (lectures and seminars), collection and evaluation of final papers. The steps to use the Google Meet platform for lectures are considered. In addition, a form of training in the field of practical tasks was mentioned - for organizing a more effective system of student education. Attempts were made to ensure not only passive but also active participation, during which the scores obtained by students are included in the final grade. Research has shown that the ability to ask questions and answer in chat after the lecture is seen by students as a good opportunity to better master the lecture material. The problem of organizing online learning was illustrated by the example of teaching disciplines at the Academy of Management and Administration in Opole.
\end{abstract}

Key words: online learning, Moodle, Google Meet, thematic blog, lecture.

\section{В Ворналкєвіч}

Академія управління і адміністрації в Ополє

вул. Нєджялковського, 18, м. Ополє, 45085, Польща

О. М. Тарануха

Національний транспортний університет

вул. Михайла Омеляновича-Павленка, 1, м. Київ, 01010, Україна

\section{О. В. Фонарюк}

Житомирський державний університет імені Івана Франка вул. Велика Бердичівська, 40, м. Житомир, 10002, Україна

\section{ОНЛАЙН НАВЧАННЯ В УНІВЕРСИТЕТАХ: ПОЛЬСЬКО-УКРАЇНСЬКИЙ ДОСВІД}

У статті представлено дослідження організації співпраці між викладачем і студентами в ході онлайн навчання. Це стосується онлайн занять (лекцій і семінарів), збору та оцінки підсумкових робіт. Показано кроки з використання платформи Google Meet для лекцій. Крім того, була згадана форма занять в області практичних завдань - для організації більш ефективної системи навчання студентів. Були зроблені спроби забезпечити не тільки пасивну, а й активну участь, під час якої отримані студентами бали включаються в підсумкову оцінку. Дослідження показало, що можливість задавати питання і відповідати в чаті після закінчення лекції розцінюється студентами як хороша можливість краще засвоїти лекційний матеріал. Проблема організації онлайн навчання була проілюстрована на прикладі викладання дисциплін в Академії управління та адміністрації в Ополе.

Ключові слова: онлайн-навчання, Moodle, Google Meet, тематичний блог, лекція. 
2021 Випуск/ Issue 48

\section{В. Ворналкевич}

Академия управления и администрации в Ополе

ул. Неджялковского, 18, г. Ополе, 45085, Польша

\section{Е. Н. Тарануха}

Национальный транспортный университет

ул. Михаила Омеляновича-Павленко, 1, г. Киев, 01010, Украина

Е. В. Фонарюк

Житомирский государственный университет имени Ивана Франко

ул. Большая Бердичевская, 40, г. Житомир, 10002, Украина

\section{ОНЛАЙН ОБУЧЕНИЕ В УНИВЕРСИТЕТАХ: ПОЛЬСКО-УКРАИНСКИЙ ОПЫТ}

В статье представлено исследование организации сотрудничества между преподавателем и студентами в ходе онлайн обучения. Это касается онлайн занятий (лекций и семинаров), сбора и оценки итоговых работ. Показаны шаги по использованию платформы Google Meet для лекций. Кроме того, была упомянута форма занятий в области практических заданий - для более эффективной системы обучения студентов. Были предприняты попытки обеспечить не только пассивное, но и активное участие, во время которого полученные студентами баллы включаются в итоговую оценку. Исследование показало, что возможность задавать вопросы и отвечать в чате после окончания лекции расценивается студентами как хорошая возможность лучше усвоить лекционный материал. Проблема организации онлайн обучения была проиллюстрирована на примере преподавания дисциплин в Академии управления и администрации в Ополе.

Ключевые слова: онлайн-обучение, Moodle, Google Meet, тематический блог, лекция.

Problem formulation. The epidemiological situation and periodic restrictions introduced in Poland and Ukraine forced universities to quickly transform into the distance learning. For this reason, the offered standard e-learning platforms and the created own implemented internet access applications were used.

There are different approaches to how e-learning is taught using digital technology. The discussion of the issues is shown in the following subjects: Operational Research, Optimization of Economic Decisions, Information Processes in Management, Information Technology, IT in Management (the Academy of Management and Administration in Opole), Economics and Pricing in Tourism, International Economics (National Transport University), Methods of Teaching Mathematics (Zhytomyr Ivan Franko State University). These are the subject areas that generally require direct teaching in classrooms, with the involvement of students solving optimization tasks, testing their manual skills directly in the computer laboratory, or individually consulting with the supervisor.

This study is divided into parts corresponding to the involvement of a lecturer at the university in the following structure: lectures on the Google Meet platform, a form of classes during exercises - also in Google Meet and the indication of access to a thematic blog, for example, run under WordPress.

Analysis of basic research and publications. In the XXI century, the development of any sphere of society is impossible without the constant introduction of innovations [2], without the active use of information technology. Today, the role of information and computer technologies (ICT) in the educational process is constantly growing. Today, it is impossible to imagine the process of organizing education in universities without the use of ICT and online platforms. Thus, in their works, researchers emphasize the need to use ICT, online technologies and online platforms in higher education in the training of future teachers [1], in the organization of artistic and labor activities of future primary school teachers [3], in the process training of future lawyers [15] and future managers [16] taking into account the emotional component of the educational process [6]. The use of ICT, online technologies and online platforms, especially when the society is in crisis, contributes to the formation and development of both subject specific and wider skills among students [20], thanks to the fulfillment of their functional duties by higher school teachers [19].

Polish and Ukrainian scholars pay significant attention to the analysis of modern challenges faced by the higher education systems of Poland and Ukraine [5; 14]. And as Budnyk with co-authors rightly point out, the range of problems facing universities in terms of distance education has expanded significantly [9].

Therefore, the use of information and computer technologies, online technologies and online platforms has become especially important 


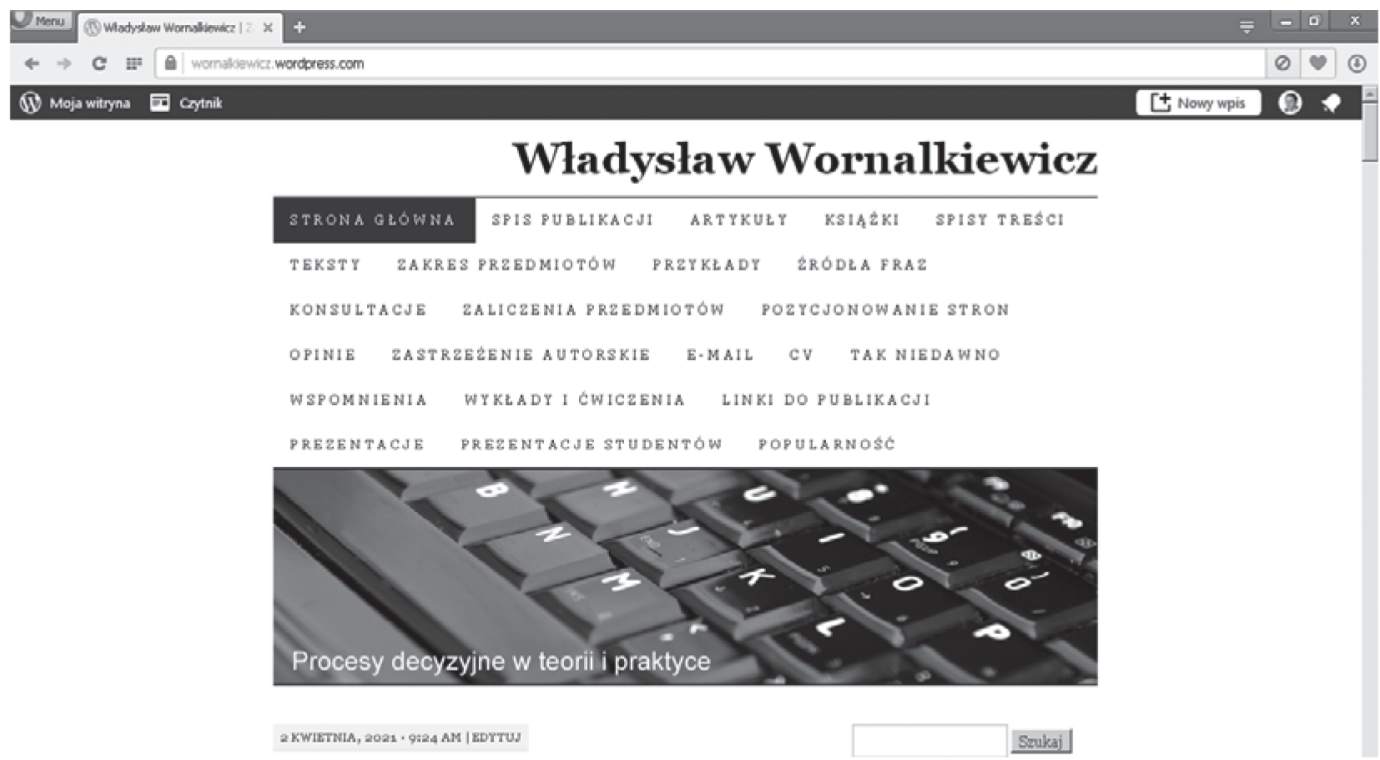

Fig. 1. Blog title page "Decision-making processes in theory and practice" Source: Own study based on a blog.

as a result of the introduction of quarantine restrictions in the educational process in $2020-$ due to the Covid-19 pandemic. It should be borne in mind that higher education is a critical factor in the development of human capital and an integral part of the economy [7; 13], and the process of forming the educational level of the population today takes place in the information society [12]. Therefore, the use of remote technologies in the educational process of universities is an absolute necessity. And the only question is which information and computer technologies, online tools and online platforms will be most effective.

Results. The purpose of this study is to analyze the experience of the online classes. In this process, there is initially a distance between the lecturers and the audience. However, with subsequent meetings and enabling direct consultation, by turning on the microphone, the parties of this form of learning are becoming more and more involved in achieving the best possible results in terms of acquiring knowledge from lectures, as well as acquiring the ability to independently solve decision-making tasks. It is also important to indicate the students' own scientific improvement by installing free online applications on their laptops and "testing" the indicated method of solving a specific problem on them.

Let's consider the ways of using online platforms for the lecture process, performing tasks or developing credit issues, as well as using a wide forum of knowledge useful to students, which is the blog run by the lecturer "Decision-making processes in theory and practice" in the Academy of Management and Administration in Opole. Access indication to a thematic blog, for example run under WordPress, is presented on figure 1.

WordPress is free software that you can use to create a beautiful website, blog or web application. This is very popular software more than $40 \%$ of all sites in the world work on WordPress, from personal blogs to major news agencies [18]. It uses the MySQL database. It is distributed under the GNU General Public License. MySQL mentioned here is a multiaccess, open-source relational database management system.

Moodle is a learning platform that is widely used in the educational process of universities around the world. It is designed to provide teachers, administrators and students with a single reliable, secure and integrated system for creating personalized learning environments. Moodle software is installed on the university server and configured according to the needs of a particular educational institution. The e-learning platform Moodle was created on the basis of Apache, PHP and MySQL or PostgreSQL. It can be run on Linux, MS Windows, Mac OS $\mathrm{X}$, NetWare 6 operating systems. Moodle is distributed as open-source software under the GNU GPL license [8]. The latest version of the Moodle platform has access to all functionalities of this platform through the administrator 
2021 Випуск/ Issue 48

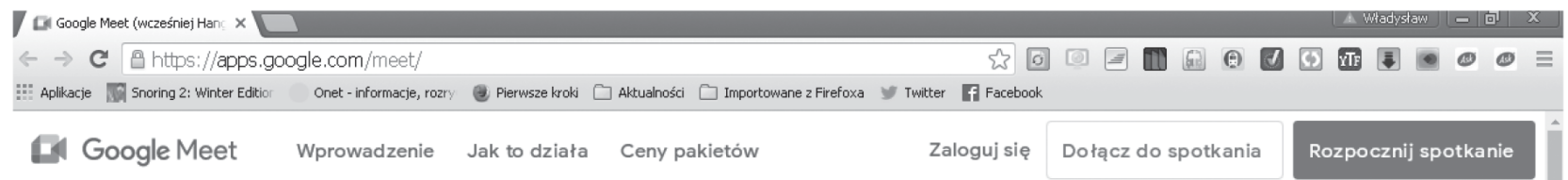

Fig. 2. The title page of the Google Meet platform

Source: Based on the Google Meet application

account [17]. It is possible to introduce a large number of courses, the platform address may be in the form of http://moj_adres.moodle.org.pl or another. Additional graphic themes adapted to be operated by mobile devices (phones and tablets) have been installed. 50 GB of disk space is available for courses and training materials. In addition, it is possible to modify and install new extensions, as well as integrate with the system for conducting webinars and teleconferences. The concept of a webinar means a type of internet seminar conducted and implemented with the use of webcast technology, which enables twoway communication between the meeting leader and participants, with the use of virtual tools enabled by the global Internet network.

Google Meet is a video communication service developed by Google [10]. It is one of the two apps to replace Google Hangouts, the other is Google Chat [11]. Now let's see what the title page of the entrance to the Google Meet platform looks like [4] - Figure 2.

Presentations of subsequent lectures in the subjects mentioned earlier are conducted from the Google Meet platform available at the universities (the Academy of Management and Administration in Opole, Poland; National Transport University and Zhytomyr Ivan Franko State University, Ukraine). For example, at the Academy of Management and Administration in Opole the classes for the fields of Management, Logistics are planned by assistants from Dean's Office, pass the timetable to the IT specialist. The same creates a note in one of the Meet platform's programs, i.e. the Calendar, just before the class. An example of the set of activities for March 20, 2021 can be seen in Figure 3.

It includes 3 time blocks:

1. Optimization of economic decisions (exercises), 10:50 am - $12.05 \mathrm{pm}$.

2. Operations Research (lecture), 12:15 am $1: 30 \mathrm{pm}$.

3. Operations research (exercises) 1:40 am 2:55 pm.

By clicking on "<" or ">", we can move to the next weeks of a given calendar of classes on the Meet platform. If a given lecturer has several accounts in Google, she/he should first select

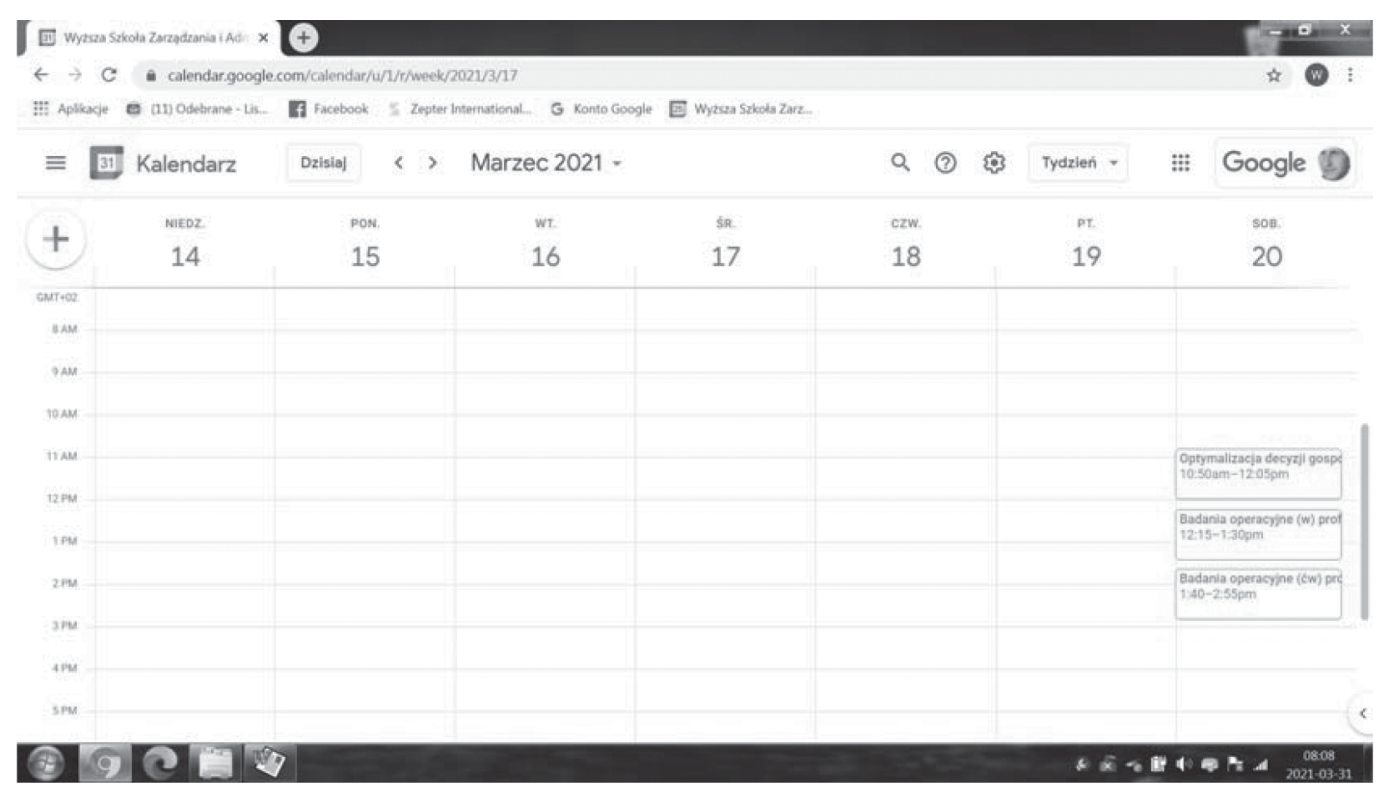

Fig. 3. A fragment of the Calendar showing the classes for March 20, 2021 Source: Own study based on the Meet platform 
the ones corresponding to the given calendar. In Figure 3, we can see an indication of the university (the Academy of Management and Administration in Opole) and the access link, namely:

calendar.google.com/calendar/u/1/r/ week/2021/3/17.

We can read that the calendar was established on a weekly basis (week) on March 3, 2021, i.e. before the lecture, which is on March 20, 2021. The IT specialist intentionally introduces new classes in the Calendar so late, because within the student groups there are constant rotations between specialties and the number of potential students changes. Calendar observations can also be made on a daily and monthly basis. Figure 3 shows that this period is a week. And now we propose to click on the second blog during the classes on March 20,2021, and these are lectures on the subject of "Operations Research".

The lecturer, day and time of the lecture are given here. As already mentioned, it should be noted that on March 17th, i.e. three days before the lecture, 4 students were registered. The whole small group of students of Logistics consisted of 25 people. In addition to the lecturer, the Dean of the Faculty of Economics and Education is automatically reported by the IT specialist. Figure 4 also lists the field of study of the 1st degree, i.e. Logistics.

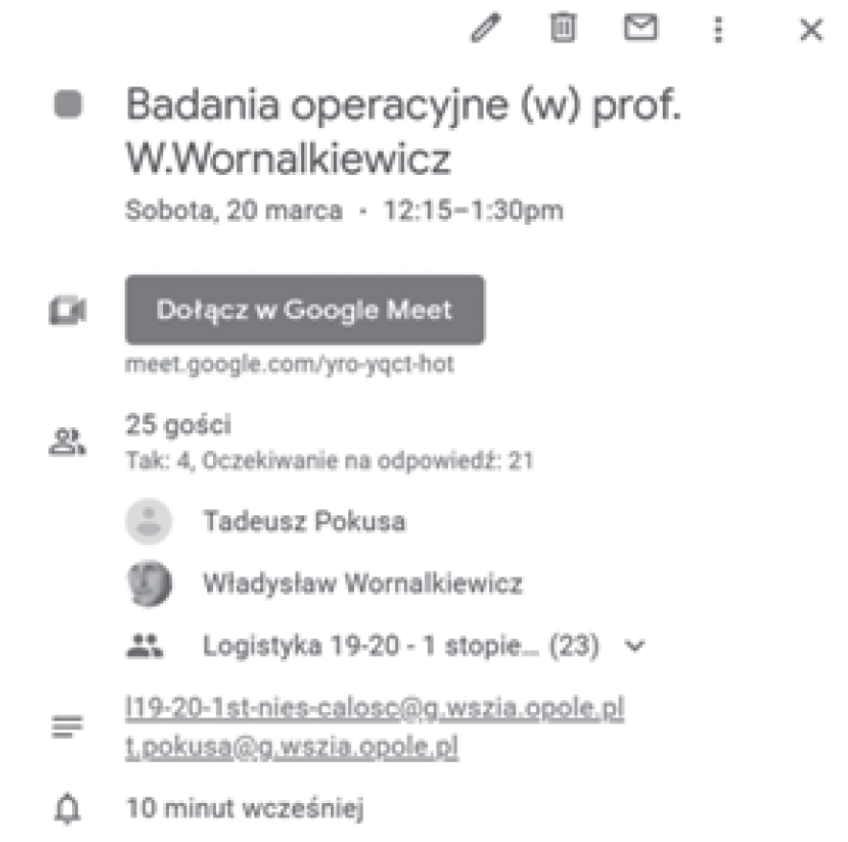

Fig. 4. Information scope of the lecture access window

Source: Own study based on the Meet platform

For the convenience of students, an e-mail to the dean is also provided. Ten minutes before the lecture, the lecturer is informed by the bell about the preparation for the presentation and the opening of other necessary electronic documents in the Meet platform disk database

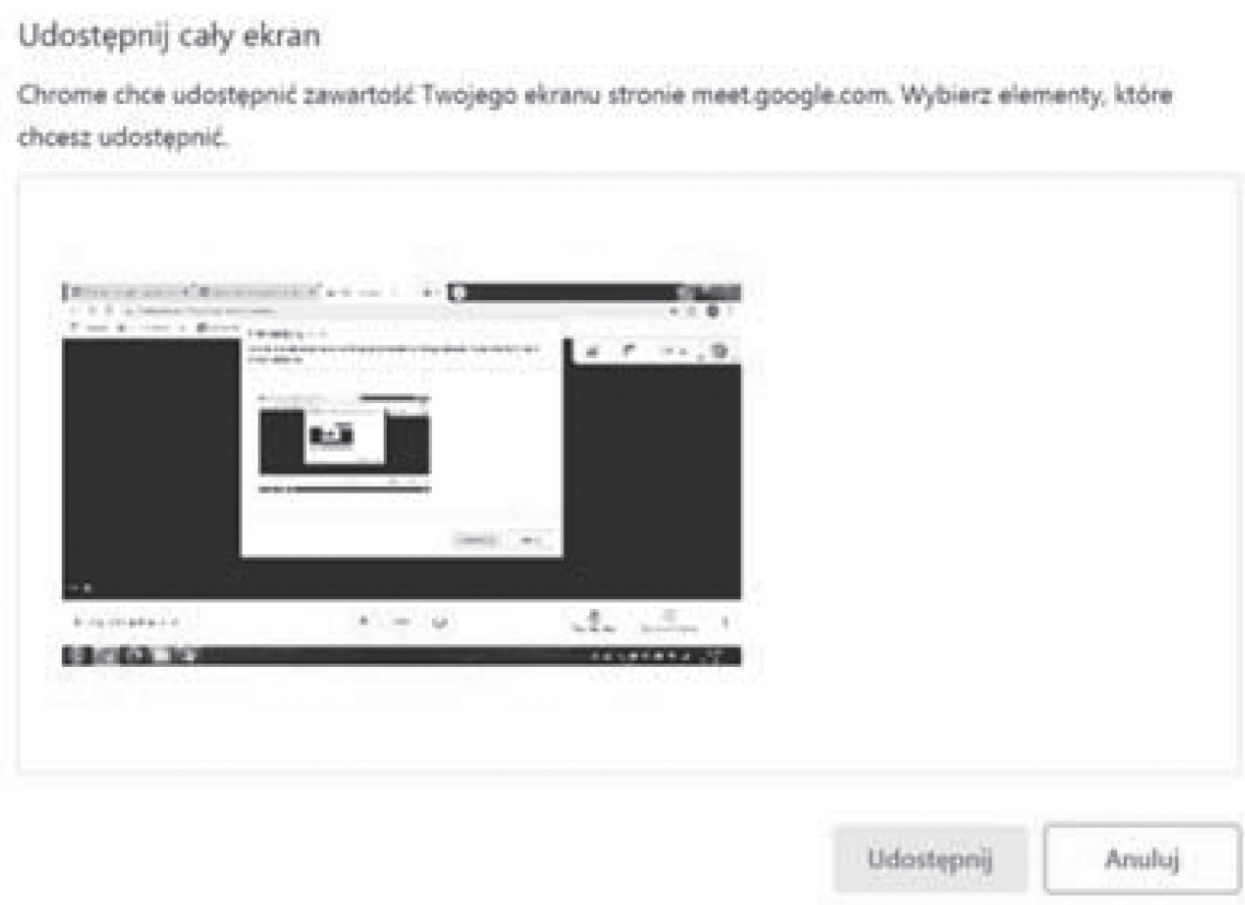

Fig. 5. An incentive to move on - use the site: meet.google.com Source: Own study based on the Meet platform 
in order to conduct a given lecture. We are now encouraged by the Google Chrome search engine to make the entire screen available "Chrome wants to share the contents of your screen with meet.google.com. Select the items you want to share" we click on the small screen view, and then on "Share" (Figure 5).

The Meet application allows not only the lecturer to join the meeting, but also students (listeners) to "talk" in the group. An identifier is given to a given Meet meeting, for example Meet - yro-yqct-hot. The "lecture" meeting may be attended by authorized persons to whom the platform administrator has given an appropriate identifier, for examplew.wornalkiewicz@g.wszia. opole.pl and have their own access password (Figure 6).

If we test access to the meeting earlier, the system informs us, "You are the only participant in the conversation". We can see that the camera and microphone have started. Before the lecture start time, the student microphones are automatically turned off to avoid "reverberation" during the presentation. However, it is possible to turn on the microphone when the lecturer asks one of the students to answer the question. During the exercises, when the audience is few, everyone tries to be active in solving decision-making tasks, so that, as I have already mentioned, you get a bonus of, for example, 0.5 points. Collecting a minimum of 3.0 points allows students to pass the subject without writing a final test, collective test or developing an individual final paper. It arouses a lot of competition among the participants and makes the given exercises more effective in terms of acquiring knowledge and skills by students. Click "Join" and we are in the meeting. As a lecturer (conducting the presentation), she/he can now download the presentation files, previously developed in Power Point, from the program called "Disk" and show the next slides to all participants of the meeting - lecture (Figure 7).

The Google Meet application has wide functionality in the form of programs represented by icons. We can access them by clicking on the circle with the "+" sign (Figure 8).

The lecturer most often uses settings of her/ his account (Account), access to e-mail (Gmail), opening a disk with folders and files (Drive), opening a scheduled activity (Calendar).

Our task is now to get the presentation of the next lecture in the subject "Operations Research". So, we click on "Disk" and a list of folders and auxiliary files for lectures and exercises. We select the most recent folder "Operations Research - 1" established on February 13, 2021 (Figure 9).
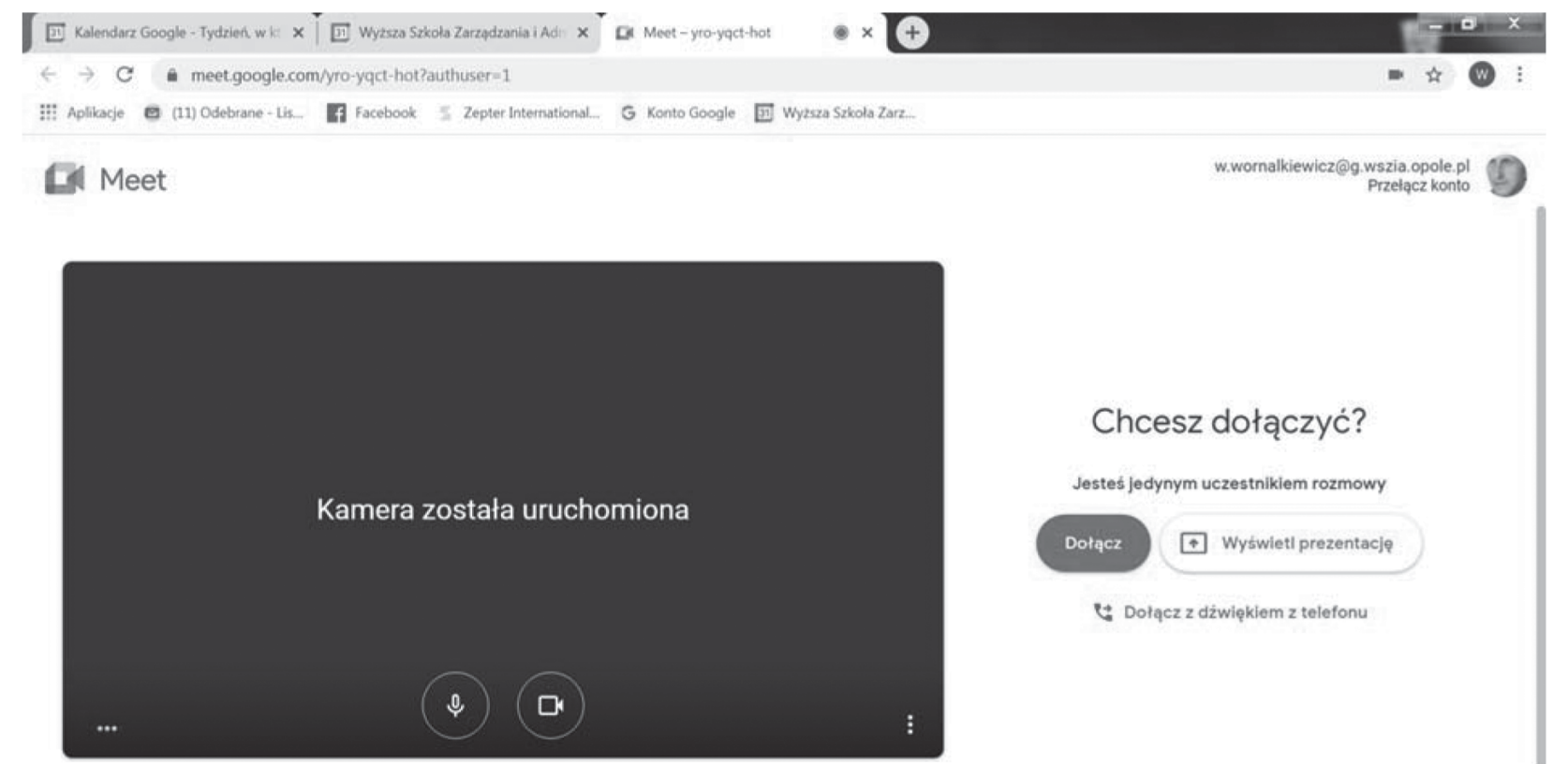

\section{Chcesz dołączyć?}

Jestes jedynym uczestnikiem rozmowy

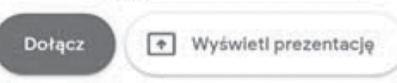

G. Dołącz z dżwiẹkiem z telefonu 


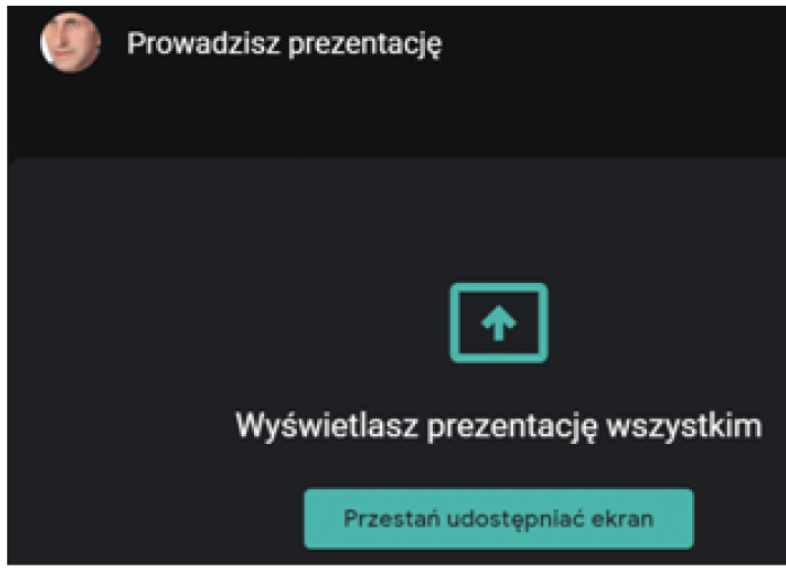

Fig. 7. Presentation display message Source: Own study based on the Meet platform

The status of this folder is "Shared with me" and the owner is " $M e$ ". Then, after opening this folder, select the presentation made in Power Point called "Operations research - lectures.ppt". If the lecturer is in the meeting, she/he can turn on her/his microphone in Meet and click on "Show presentation in full screen to everyone". The initial view of a fragment of the presentation slides is shown in Figure 10. We browse through the slides with the $<$ PgDn $>$ or $<$ PgUp $>$ keys, until we come to the lecture on a given day. After the lecture is finished, we exit the presentation by pressing the
2021 Випуск/ Issue 48

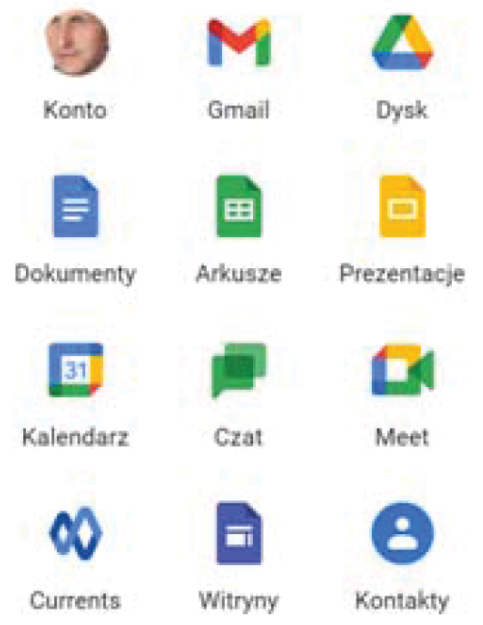

Fig. 8. Ikony dostępu do programów platformy Google Meet (fragment) Source: Own study based on the Meet platform

$<$ Esc $>$ key, close the file by pressing " $\mathrm{X}$ " in the tab menu, close the presentation for everyone and click on the "Chat" icon.

We finish the lecture 10 minutes before the time in the Calendar. The lecturer looks into the "Meeting details", learns about the number of people who are participating. After clicking on the "Chat" icon, you can read the questions and answer them one by one to students who have their

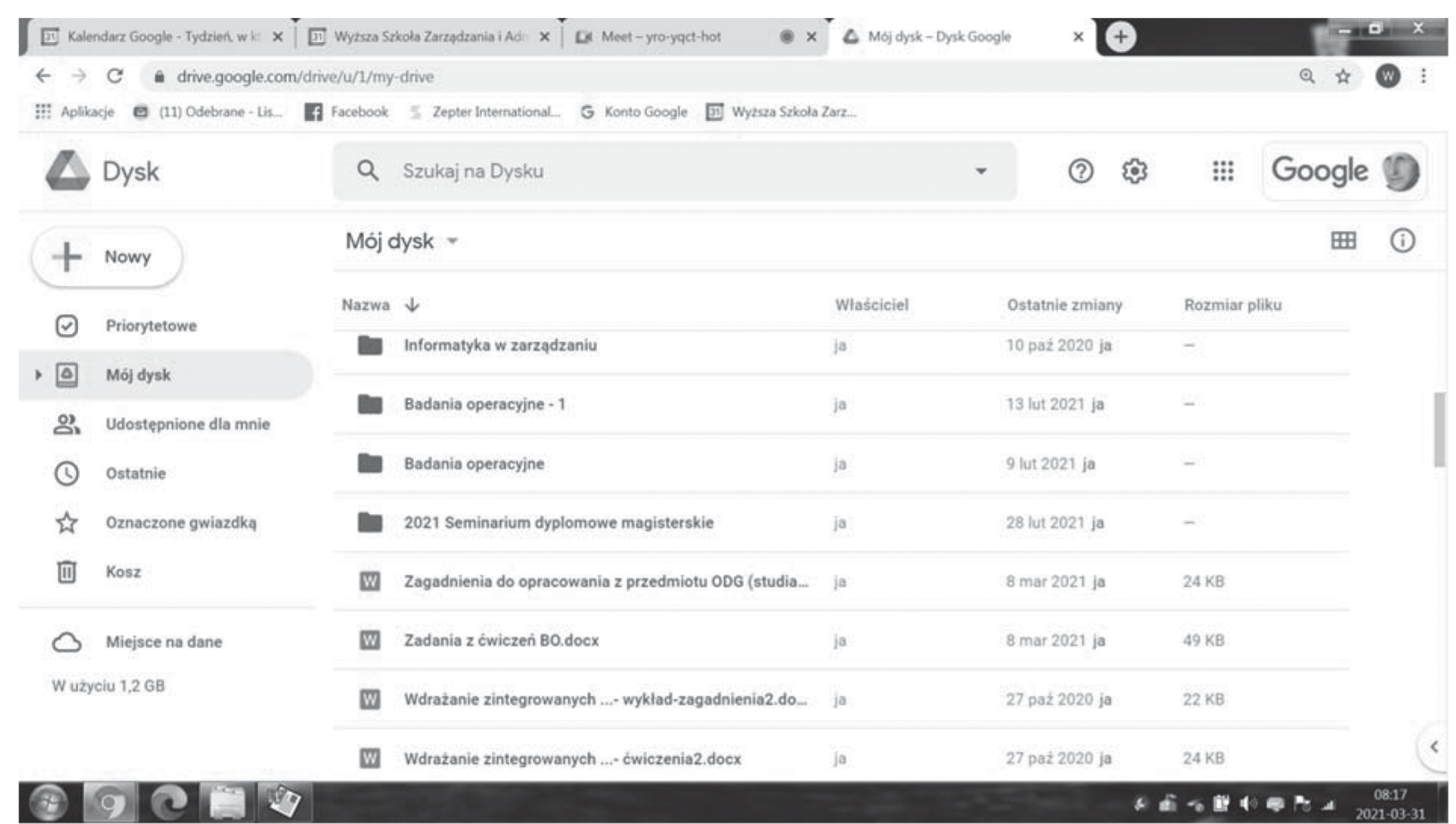

Fig. 9. Folders and files under "My Drive" (excerpt) Source: Own study based on the Meet platform 
2021 Випуск/ Issue 48

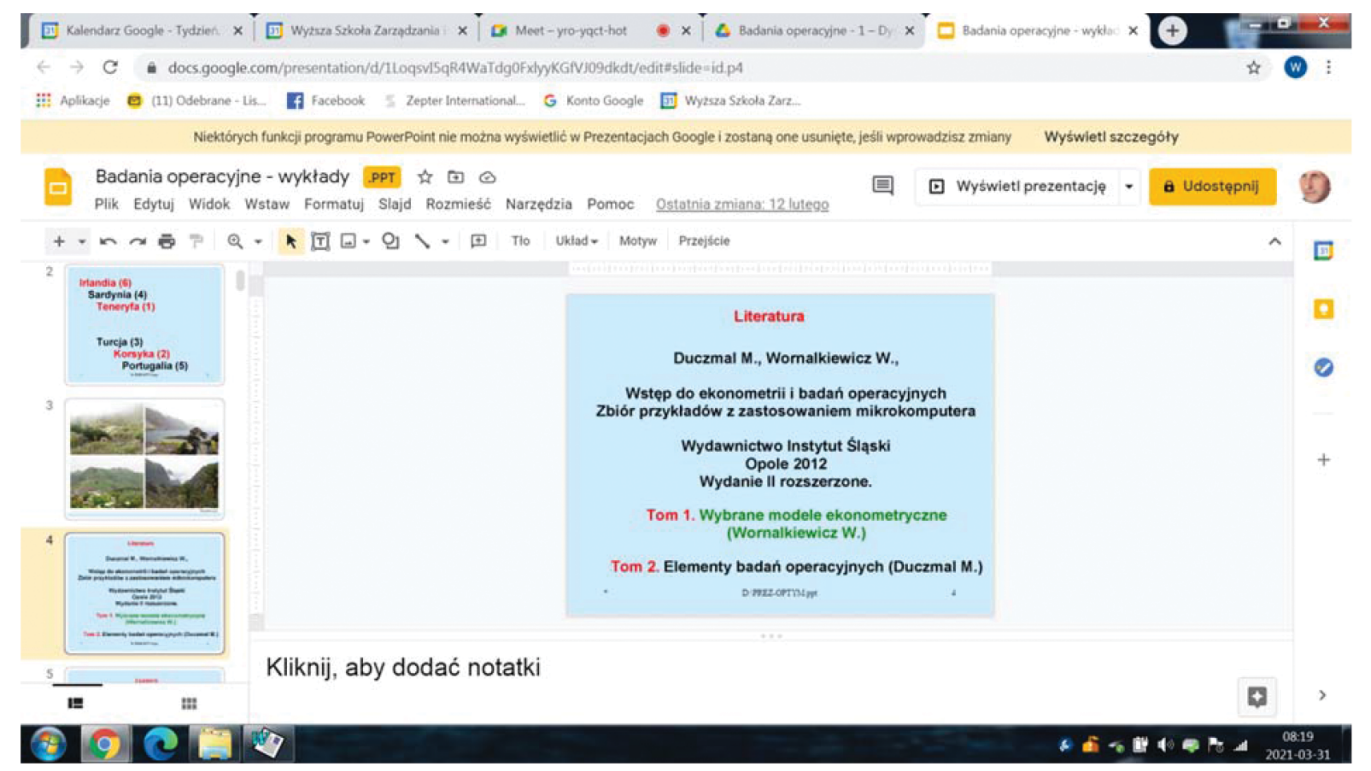

Fig. 10. Presentation slides "Operations research - lectures.ppt" (excerpt) Source: Own study based on the Meet platform

microphones turned on. It is also possible to send a short message to all listeners of a given meeting, e.g. link to the publication, e-mail, etc.

Conclusion. The solutions for conducting online classes may vary depending on the type of subject taught. Lecturers behave slightly differently when they provide descriptive knowledge, and differently if - as presented in this study, students have to learn quite complex mathematical procedures in the field of solving optimization tasks.

Rapid progress in the field of computer science forces the lecturer to develop their own scripts, based on current information and currently available applications, or the offered equipment from the broadly understood IT technology. We hope that the presented procedure will be helpful in choosing the right path in quite difficult online academic education on the Internet. It is also worth noting the appropriateness of the teacher's own blog on the subject, in which you can post useful information for students.

\section{СПИСОК ВИКОРИСТАНИХ ДЖЕРЕЛ ТА ЛІТЕРАТУРИ:}

1. Алєксєєва Г.М. Використання інформаційно-комунікаційних технологій в процесі професійної підготовки студентів педагогічних вузів. Актуальні питання фізико-математичної освіти. 2014. С.184-191.

2. Боровік Л.В. Інновації - основний метод активізації інвестиційних процесів у сільському господарстві. Міжнародний науково-практичний журнал Фінансовий простір. 2020. №1 (37). C.8-15. DOI: https://doi. org/10.18371/fp.1(37).2020.201541

3. Бучківська Г. Використання інформаційно-комунікаційних технологій у процесі художньо-трудової діяльності майбутніх учителів початкових класів. Наукові записки Тернопільського національного педагогічного університету імені Володимира Гнатюка. Серія: Педагогіка. Тернопіль: Вид. відділ ТНПУ, 2018. № 1. C. 39-46. DOI: https://doi.org/10.25128/2415-3605.18.1.6

4. Відеозустрічі преміум-класу. Безкоштовний доступ для всіх. URL: /rhttps://apps.google.com/meet/

5. Карпенко А. В., Юртаєв Д. М. Вища освіта України: проблеми та перспективи. Держава та регіони. Серія: Економіка та підприємництво. 2015. № 6 (87). C. 96-101. http://www.econom.stateandregions. zp.ua/journal/2015/6_2015/22.pdf

6. Лисенкова І.П. Когнітивний підхід у дослідженні емоційної сфери. Психологія і особистість: Науковий журнал. 2018. № 2 (14). С. 59-69.

7. Несторенко Т.П., Бордоусов О.В. Ценность высшего образования для индивида. Вісник Хмельницького національного університету. Економічні науки. 2015. № 3(3). С. 171-174.

8. About Moodle. URL: https://docs.moodle.org/310/en/About_Moodle 
9. Budnyk O., Protas O., Berezovska L., Yablon L., Rusakova O. Current challenges in the conditions of distance education: inquiry-based learning. Revista inclusiones. 2021. Vol. 8. P. 210-222. URL: https://cutt.ly/Jblxrc5

10. Johnston, Scott, Meet the new Hangouts, Google, Archived from the original on March 14, 2017. Retrieved March 15, 2017.

11. de Looper, Christian. Google will begin shutting down the classic Hangouts app in October. DigitalTrends.com. Archived from the original on August 4, 2019. Retrieved September 5, 2019.

12. Martynovych N., Boichenko E., Vivchar O., Myskova N., Popovych O., Kasianenko O. Formation of Educational Level of the Population of Ukraine in the Conditions of Formation of Information Society. International Journal of Engineering and Advanced Technology. Vol. 9 (1), October 2019, pp. 6406-6411

13. Nestorenko T. Economic Impact of International Students on the Host City: Case of University of Economics in Bratislava. 3rd Teaching \& Education Conference, the International Institute of Social and Economic Sciences, June 28 - July 1, 2016 in Barcelona, Barcelona, Spain. https://cutt.ly/nblz0Hy

14. Ostenda A., Nestorenko T., Ostenda J. Practical education on a higher level in Poland: example of Katowice School of Technology. Наукові записки Бердянського державного педагогічного університету. 2018. Вип.1. С.186-190. DOI 10.31494/2412-9208-2018-1-1

15. Sherman M. Research of Influence of Computer Training of Future Lawyers on Indicators of Academic Achievement. Information Technology in Education: Scientific Journal. 2014. vol 19. pp. 34-44. http://eKhSUIR. kspu.edu/handle/123456789/7150.

16. Stupak O. Educational technologies in training future managers. Advanced Education. 2020. 15. P. 97-104. http://ae.fl.kpi.ua/article/view/200229. https://doi.org/10.20535/2410-8286.200229.

17. Uruchom własną platformę edukacyjną Moodle! https://moodle.org.pl/

18. Wordpress. https://uk.wordpress.org/

19. Zhukova O. Activity of A Higher School Teacher On Forming Soft Skills For Students of Humanitarian And Natural Specialties: Functions And Requirements. Scientific Journal of Polonia University. 2020. 39(2). pp. 229-241. DOI https://doi.org/10.23856/3931

20. Zhukova O., Mandragelya V, Janužis G. Development of Soft Skills of Students As Future Teachers In Conditions of Crisis In Society. Education during a pandemic crisis: problems and prospects. Monograph. Eds. Tetyana Nestorenko \& Tadeusz Pokusa. Opole: The Academy of Management and Administration in Opole, 2020. pp.151-157.

\section{REFERENCES:}

1. Alekseeva, H. M. (2014). The use of information and communication technologies in the process of professional training of students of pedagogical universities. Aktualni pytannia fizyko-matematychnoi osvity. № 3, pp. 184191. (in Ukrainian).

2. Borovik, L. V. (2020). Innovatsiyi-osnovnyy metod aktyvizatsiyi investytsiynykh protsesiv u sil's'komu hospodarstvi. Finansovyy prostir. vol.1(37), pp. 8 - 15. (in Ukrainian).

3. Buchkivska, G. (2018). The use of information and communication technologies in the process of artistic and labor activities of future primary school teachers. Scientific notes of Ternopil National Pedagogical University named after Volodymyr Hnatyuk. Series: Pedagogy, 1, pp. 39-46. (in Ukrainian).

4. Videozustrichi preim-klasu. Bezkoshtovnyi dustup dlia vsih. https://apps.google.com/meet/

5. Karpenko, A. V., Yurtaiev D. M. (2015). Vyshcha osvita Ukrainy: problemy ta perspektyvy. Derzhava ta rehiony. Seriia: Ekonomika ta pidpryiemnytstvo. № 6 (87). pp. 96-101. (in Ukrainian).

6. Lysenkova, I.P. (2018). Kohnityvnyi pidhid u doclidzhenni emociynoi sfery. Psyholohiia i osobystist': Naukovyi zhurnal. № 2 (14). pp. 59-69. (in Ukrainian).

7. Nestorenko, T.P., Bordousov O.V. (2015). Tsennost' vyssheho obrazovaniia dlia indyvida. Visnyk Khmelnytskoho natsionalnoho universytetu. Ekonomichni nauky. № 3(3). pp.171-174. (in Russian) http://nbuv.gov.ua/UJRN/ Vchnu_ekon_2015_3(3)_35. (in Russian).

8. About Moodle. https://docs.moodle.org/310/en/About_Moodle

9. Budnyk, O., Protas O., Berezovska L., Yablon L., Rusakova O. (2021). Current challenges in the conditions of distance education: inquiry-based learning. Revista inclusiones. Vol. 8. pp. 210-222. URL: https://cutt.ly/ Jblxrc5

10. Johnston, Scott, (2017). Meet the new Hangouts, Google, Archived from the original on March 14, . Retrieved March 15, 
2021 Випуск/ Issue 48

11. de Looper, Christian. Google will begin shutting down the classic Hangouts app in October. DigitalTrends.com. Archived from the original on August 4, 2019. Retrieved September 5, 2019.

12. Martynovych, N., Boichenko E., Vivchar O., Myskova N., Popovych O., Kasianenko O. (2019). Formation of Educational Level of the Population of Ukraine in the Conditions of Formation of Information Society. International Journal of Engineering and Advanced Technology. Vol. 9 (1), pp. 6406-6411

13. Nestorenko, T. (2016). Economic Impact of International Students on the Host City: Case of University of Economics in Bratislava. 3rd Teaching \& Education Conference, the International Institute of Social and Economic Sciences, June 28 - July 1, in Barcelona, Barcelona, Spain. https://cutt.ly/nblz0Hy

14. Ostenda, A., Nestorenko T., Ostenda J. (2018). Practical education on a higher level in Poland: example of Katowice School of Technology. Scientific notes of the Berdyansk State Pedagogical University. Series: Pedagogical Sciences: zb. nauk. prats. Vol.1. BSPU, 186-190.

15. Sherman, M. (2014). Research of Influence of Computer Training of Future Lawyers on Indicators of Academic Achievement. Information Technology in Education: Scientific Journal, vol. 19. Kherson: KSU. pp. 34-44. http:// eKhSUIR.kspu.edu/handle/123456789/7150.

16. Stupak, O. (2020). Educational technologies in training future managers. Advanced Education. № 15, pp. 97104. http://ae.fl.kpi.ua/article/view/200229. https://doi.org/10.20535/2410-8286.200229.

17. Uruchom własną platformę edukacyjną Moodle! https://moodle.org.pl/

18. Wordpress. https://uk.wordpress.org/

19. Zhukova, O. (2020). Activity Of A Higher School Teacher On Forming Soft Skills For Students Of Humanitarian And Natural Specialties: Functions And Requirements. Scientific Journal of Polonia University. №39 (2). pp. 229-241. DOI https://doi.org/10.23856/3931

20. Zhukova, O., Mandragelya V, Janužis G. (2020). Development Of Soft Skills Of Students As Future Teachers In Conditions Of Crisis In Society. Education during a pandemic crisis: problems and prospects. Monograph. Eds. Tetyana Nestorenko \& Tadeusz Pokusa. Opole: The Academy of Management and Administration in Opole,. pp.151-157. 